\title{
A Spinozistic model of moral education
}

\author{
Johan Dahlbeck, johan.dahlbeck@mah.se
}

\section{Introduction}

Early modern rationalist and metaphysician Benedict de Spinoza (1632-1677) is not generally thought of as a philosopher of education. Admittedly, he is not primarily thought of as a moral philosopher either. More typically, Spinoza's texts are studied because they provide exciting and unorthodox views on metaphysics through which we may reevaluate more dominant understandings (Curley, 1969; Bennett, 1984; Melamed, 2013), and, in a broader historical sense, because he is acknowledged as one of the more radical figures of the European Enlightenment (Israel, 2002). The fact is, however, that Spinoza's ethical theory, placed at the center of his metaphysical system (Kisner \& Youpa, 2014), makes for a very constructive - albeit perhaps somewhat counterintuitive - starting point for theorizing about moral education (Dahlbeck, 2016). The reason for this, I would argue, is that his ethical theory is profound, well argued and realistic. This, in turn, is due in part to Spinoza's naturalistic account of human psychology (following directly from his substance monism) and to his subsequent denial of a free (unrestrained and uncaused) will and of the objectivity of moral knowledge. Spinoza's ethical theory is of significance for moral education as it offers a form of virtue ethics that manages to construct a naturalistic account of virtue that is both non-teleological and not dependent on a transcendent source. ${ }^{1}$ Consequently, his ethical theory offers a viable response to some of the most enduring problems of moral education insofar as it may reconcile a traditional understanding of virtue with a thoroughly naturalistic understanding of the will. For Spinoza, the cultivation of a virtuous character need not be synonymous with personal decision-making. Instead, a virtuous character is marked by an adequate understanding of the natural limitations of a human being, and this understanding is far more likely to lead to an enduring sense of happiness than a morality that supposes that humans are somehow exempt from the causal order of nature. This means that Spinoza can offer a philosophical groundwork for an educational account that is geared to the formation of a virtuous character while avoiding any appeal to supernatural forces. While this makes Spinoza an unlikely candidate insofar as he proposes an ethical theory denying the reality of a free will and therefore lacking an account of moral responsibility, I would argue that it is precisely this aspect that makes his ethical theory interesting to consider in the context of moral education. This is so as it provides a good example of what moral education might look like when it is thoroughly naturalized.

The essay will proceed by examining Spinoza's rationalism which provides the framework for his peculiar form of virtue ethics, taking special care to highlight his constructivist account of moral knowledge (Jarrett, 2014). A key part of this involves looking closer at the philosophical basis and the practical implications of Spinoza's puzzling statement that selfpreservation is the only foundation of virtue (E4p22 $\left.c^{2}\right)$. Having done so it goes on to investigate some striking educational implications of this position, focusing in particular on discussing the relation between Spinoza's ethical egoism and the broader social and political role of moral education. In the next part of this essay, some concrete effects of Spinoza's denial of a free will and of the reality of good and evil are examined more closely, focusing 
especially on resolving the apparent tension between moral education and Spinoza's denial of moral responsibility. Having looked at some of the constraints placed on Spinoza's ethical theory by his metaphysics, the essay will turn to some of its practical consequences for moral education. It will do so by fleshing out some practical implications of Spinoza's theory of virtue, which hinges on the student's acquisition of adequate knowledge and the reordering of ideas as a practical way of escaping the bondage of the passions. It is argued that while this can help build a case for the value of turning to Spinoza's philosophy in the context of moral education, it is doubtful whether the account outlined can be labeled a genuine form of moral education. This conclusion hinges on the insight that while Spinoza's ethical theory is deeply educational at heart it appears to lack some of the key characteristics usually associated with moral education. Instead, what emerges is a form of moral education that is construed broadly enough to encompass all of education rather than designating an aspect or a particular subfield of education.

Before looking closer at the relation between Spinoza's rationalism and his ethical theory it is called for to survey some of the available studies on Spinoza and moral education so as to arrive at a clearer idea of what, more precisely, the present essay aims to accomplish.

\section{Existing literature on Spinoza and moral education}

This essay does not mark the first attempt to engage with Spinoza's philosophy in the context of moral education. Although very few in number, there are some notable examples where Spinoza's ethics is appealed to as a model for moral education (or, in a broader sense, for a conception of education grasped from the point of view of ethics). In order to come to see more clearly how the present essay contributes to a Spinozistic understanding of moral education, it will be useful to, however briefly, summarize the main currents of existing literature on Spinoza and moral education.

In "Spinoza on returning hatred with love" (1988), Brent A. Singer turns to Spinoza's proposition stating that '[ $\mathrm{h}$ ] $\mathrm{e}$ who lives according to the guidance of reason strives, as far as he can, to repay the other's hate [...] with love' (E4p46) in order to highlight 'the role of moral education in determining conduct according to nature' (Singer, 1988, p. 3). I take Singer's main aim to be to illustrate how moral education can be utilized for the purpose of habituating students cognitively into associating hateful acts with loving responses. Rather than responding with hate - which, as Spinoza argues, will only serve to generate more hate which, in turn, will be harmful to all those involved - the rational response would be to respond with love, as love has the capacity of countering hate by virtue of being an opposed emotion. The more students learn to do this, the more powerful they will become, and the more they will benefit from being in a community with others who respond in a similarly rational way. Because Spinoza understands reason to be an essential feature of human nature, moral education - on Singer's account - can be conceived as a useful means by which students may be brought more in line with their nature, which is to persevere and to flourish in being (E3p6). While I am sympathetic to Singer's conclusions, I am unconvinced that this is all - or even the most central aspect - that Spinoza has to offer moral education. Besides, I find it notable that Singer's account does not directly confront what to my mind is the greatest challenge for a convincing account of moral education drawing on Spinoza's philosophy; namely Spinoza's causal determinism. While Singer argues that by avoiding 'Spinoza's less popular or less understood metaphysical claims' he will also avoid having to 
introduce 'undue complications which would require extensive explication of the Ethics' (1988, p. 4), I am unconvinced that this is a successful strategy. This is so mainly because, as Spinoza scholar Karolina Hübner notes, 'Spinoza's metaphysical commitments profoundly circumscribe his potential moral commitments' (Forthcoming, p. 2) which indicates that an account of moral education drawing from Spinoza's philosophy is difficult to conceive divorced from its metaphysical foundation.

In "Spinoza as educator" (2008), Nimrod Aloni aims to outline 'an empowering and liberating pedagogy' drawing on Spinoza's ethical theory. Aloni argues that Spinoza offers a form of eudaimonistic ethics especially well-suited for this purpose. While Aloni does address the threat of Spinoza's determinism he opts for a largely humanistic reading of Spinoza. While this is done convincingly, it assumes that Spinoza's anti-humanist ideas (see Melamed, 2011) are of less importance for an educational account than his social agenda promoting 'a society based on the principles of reason, liberty and justice' (Aloni, 2008, p. 534). I take this to be problematic insofar as it tends to divorce Spinoza's ethical project from its metaphysical foundation in a way that assumes that his causal determinism is less pervasive and thoroughgoing than I aim to argue that it is. In fact, one of the main objects of my essay is to show that a coherent account of moral education based on Spinoza's philosophy needs to treat his causal determinism as a necessary point of departure rather than a metaphysical problem to be disregarded or downplayed in favor of his more popular views on 'a rational social contract that secures freedom, fairness, and peace' (ibid.).

Heidi M. Ravven's "Spinoza's materialist ethics" (1990) marks an endeavor to construe Spinoza's overall ethical project in terms of a call for the education of desire. In doing so she seeks to downplay overly intellectualist readings of Spinoza, focusing instead on Spinoza's psychological account where desire is construed as the fundamental striving to persevere in being rather than as a mere threat to reason. By doing so she aims to place Spinoza's ethics 'in the larger context of human biology and psychology rather than in either the narrow compartmentalized context of social justice, on the one hand, or of the narrowly intellectualist metaethics of rules and reasoning, on the other' (p. 72). This goes to highlight Ravven's focus on drawing out the benefits of Spinoza's naturalism for his ethical theory in a way that accords with the focus of the present essay. Whereas Ravven's chief aim is to place the education of desire at the center of Spinoza's ethical theory, however, my aim is rather to focus on investigating how Spinoza's unconventional ethical theory (unconventional in the sense that it lacks some key features generally required by a moral theory) can be conceived in terms of a credible foundation for moral education; not in spite of, but rather because of the constraints posed by his causal determinism.

Other notable contributions to the literature on Spinoza and education include Genevieve Lloyd's "Spinoza and the education of the imagination" (1998), highlighting the often overlooked interdependency of the imagination (being a source of confused knowledge) and reason in Spinoza; Tapio Puolimatka's "Spinoza's theory of teaching and indoctrination" (2001), addressing the tension between the indoctrination of passive students and the promotion of autonomous individuals; and Jan Derry's "The unity of intellect and will" (2006), investigating important connections between Spinoza's naturalism and Vygotsky's educational theory. I will not comment on these papers in more detail simply because they do not address moral education specifically. 


\section{Spinoza's rationalism}

In order to arrive at a good understanding of Spinoza's ethical theory it helps to begin by outlining his overarching rationalist framework. The reason for this is that Spinoza's ethical theory is very much conditioned by his rationalism. In brief, Spinoza's rationalism states that all things are explainable according to the same basic principles. That is, nothing is exempt from the governing laws of nature and the way to understand things must therefore be the same regardless of which particular thing one aims to explain. Spinoza states this explicitly in the Preface to Part 3 of the Ethics:

$[T]$ he laws and rules of Nature, according to which all things happen, and change from one form to another, are always and everywhere the same. So the way of understanding the nature of anything, of whatever kind, must also be the same, namely, through the universal laws and rules of Nature. (E3pref)

Jonathan Bennett (1984) refers to this as Spinoza's 'explanatory rationalism' (p. 29) and it argues that (1) the world is explainable in principle and that (2) the only way to explain things rationally is by understanding their chains of natural causes. For Spinoza (as for his predecessor Descartes), the world may be approached in terms of things being either selfcaused or things being caused by external things (E1a1). Spinoza thereby asserts that all things can be explained through their causes. If we understand a thing's cause we understand what it is essentially, i.e. what is necessary for it to be conceivable (E2D2). When something is self-caused it is self-explained and when it is caused by something external to it, it needs to be explained through these external causes. The only self-caused thing Spinoza will admit is God or Nature (E1p14 by E1D3), ${ }^{3}$ which corresponds to nature as indivisible and fully active substance. Everything else - i.e. all the particular things that are in God or Nature - is, to different degrees, caused by something else (E1D5).

The essence of particular things, for Spinoza, is the striving to become more self-explained and thereby more self-caused (E3p6). The way to become more self-explained is, as indicated in the scheme outlined above, to come to understand oneself better. The more we understand ourselves rationally, the more we can explain ourselves, and the more selfdetermined we will become. Insofar as the striving for self-preservation and selfdetermination is an ethical concern for Spinoza, it follows that reason, by virtue of which we become more self-determined, is itself an ethical concern. That is, to be able to explain ourselves and the world around us in rational terms is, for Spinoza, an ethical matter insofar as this will be conducive to our happiness and to our gradual freedom from external causes.

There is a seeming tension between Spinoza's ethical ideal of self-determination and his deterministic metaphysics positing that everything in nature is causally determined by something else. It begs the quest of what it means for a thing to strive in a world conceived in strictly deterministic terms? It is clear that striving, from Spinoza's point of view, does not imply the freedom to act contrary to our nature. It does not involve a free will if by this we mean an uncaused will arising spontaneously. On the contrary, the more we act from our nature as striving things the freer we become. As Hübner notes: 'For this reason, striving has to be understood in conditional or hypothetical terms, as a claim about what a thing would do, were it left to its own devices, and per impossible free from the influence of things more 
powerful and essentially different from it (E4a1)' (Forthcoming, p. 23). Since we are always under the influence of external things, however, our striving to be self-determined is always hampered. This natural limitation is what sets the stage for Spinoza's ethical theory to begin with. It posits that there is a sense in which we all strive to become free and that this striving is an essential feature of our nature as striving things. Since there are other things in nature (whose striving is potentially detrimental to us) striving at the same time, however, the ethical project concerns finding out which things will empower us and which will not.

Spinoza's Ethics may be read as a general guide to the formation of a good character where a good character is characterized by a good understanding of natural causation. It begins with an overarching metaphysical system establishing that everything that exists is an expression (mode) of nature (substance) and that what define these things is the striving to persevere and flourish in being (E3p7). All things are the same in this regard. Spinoza moves on to his account of the human mind (being another thing determined to strive for perseverance) in order to establish a path to human freedom. By conceiving of the human mind as a finite mode, he equates it with the mind of any other finite mode, albeit relatively more complex than most other known minds. ${ }^{4}$ For Spinoza, there is nothing exceptional about a human being that would warrant an elevated status from the perspective of nature qua substance. This has led some commentators to label Spinoza an anti-humanist (Melamed, 2011). This is not to say, however, that Spinoza is uninterested in matters concerning human well-being, quite the opposite, but it serves to highlight the fact that he refuses to adjust his account of the human being according to popular fictions and superstitions. This is evident from the fact that Spinoza's account of the affects follows his general metaphysical outline. Accordingly, he states that he will 'consider human actions and appetites just as if it were a question of lines, planes, and bodies' (E3pref). This way we see that rationality and ethics are inseparable concepts for Spinoza. It remains to be seen how Spinoza understands the striving for self-preservation to relate to the development of virtue, but before looking closer at this it is called for to situate the concept of virtue in the context of moral education.

\section{Self-preservation as the foundation of virtue}

Kristján Kristjánsson has recently described Aristotelian character education in terms of 'a form of moral education focusing on the development of virtues' $(2015, p$. 2). This means that forming a clear idea of the concept of virtue becomes central for the construction of a theory of moral education based on the development of a virtuous character. In the classical Aristotelian sense, a virtue is quite simply a means to a flourishing life. That is, 'it is impossible to achieve eudaimonia without being morally good - without actualizing the moral virtues' (Kristjánsson, 2007, p. 15). Eudaimonia, for Aristotle, is roughly the same as a flourishing, balanced and happy existence. In order to learn how to become happy - in this more profound and sustainable sense - we need to develop virtues. What, then, is a virtue more specifically?

Aristotle construes ethical virtues as intermediary states balancing between defect and excess. The art of living a well-balanced life is kept in check by the desire to strive for acting on virtues placed between two extreme poles, both of which are equally undesirable. For instance, the virtuous person will strive to always act generously, avoiding both the deficiency of greed (personified by the miser) and the excess of wastefulness (personified by 
the wasteful and careless person). To live guided by ethical virtues such as generosity is to live a flourishing life. Displaying traits such as generosity, honesty and courage therefore distinguishes a moral person from an immoral person, the latter being marked by traits such as greed, deceitfulness and cowardice. These traits are instrumental for the realization of a flourishing life, but in and of themselves they are merely parts of a greater machinery geared at 'the formation of somebody's character, which accommodates a whole range of virtues and in which cognition and emotion ideally form a unity' (Sanderse, 2015, p. 383).

To achieve this kind of life is an end in itself, which is why eudaimonia is conceived as the highest good to strive for. This means that eudaimonia is desirable for itself and not for the purpose of attaining some other good and, correspondingly, that all other goods are desirable for the sake of eudaimonia (Kraut, 2014). This makes eudaimonia the ultimate end (telos) of human life and to be able to strive for this kind of perfection is what distinguishes the human being from other forms of life naturally incapable of this kind of intellectual happiness.

The attainment of happiness (in the sense of eudaimonia) is central for Spinoza as well and it plays an important part in his ethical theory. It is not, however, construed as a final end in the sense that it represents the natural perfection of human nature. For Spinoza nothing is more or less perfect than anything else from the perspective of nature. Things are only deemed imperfect to the extent that they are considered detrimental or bad from a particular perspective - i.e. for someone else perceiving it (E4pref). Imperfection, that is, is a mode of thought rather than a state of being. From the perspective of nature, everything is always perfect. From the limited perspective of a human being, however, an earthquake is certainly bad, but it is a mistake, Spinoza claims, to assume that this perceived imperfection is in any way a true reflection of the nature of the earthquake. Accordingly, Spinoza writes that 'I do not attribute to Nature beauty, ugliness, order or confusion. It is only with respect to our imagination that things can be said to be beautiful, ugly, well-ordered or confused' (Letter $32^{5}$ ).

Happiness, for Spinoza, is good because it increases our conatus, our striving to persevere and to flourish in being (E3p6). Our striving to persevere, in turn, is our essence (E3p7); i.e. it is what defines us. In fact, as we saw above, the striving to persevere is the essence of every finite thing. ${ }^{6}$ Since the striving to persevere in being is a matter of degree, things can be differentiated by the particular degree of power by which they do this. Hence, the conatus of a stone defines it insofar as it determines the degree of power with which the stone strives to persevere in being. The same goes for you or me. From this it follows that what is good is simply that which will help us persevere in being (E4D1). Since happiness is understood as an increase in the power to persevere, it is good. Correspondingly, whatever hinders our striving is bad (E4D2). This conception of virtue hinges on Spinoza's understanding that the foundation of virtue is self-preservation. Spinoza states this explicitly in E4p22c, which reads: 'The striving to preserve oneself is the first and only foundation of virtue'. Accordingly, anything that is conducive to self-preservation is deemed to be virtuous. That is, anything that helps us persevere in being is virtuous and anything that hinders this striving is a vice. This conception of virtue - as anything that helps me persevere in being - strongly hints at Spinoza's leanings toward psychological and ethical egoism (Nadler, 2013). If the foundation of virtue is to persevere and flourish in being, and if what is instrumental for this striving 
differs to some extent from individual to individual, then this means that my ethical striving will be geared for my own self-preservation without at the same guaranteeing the selfpreservation of anything else. ${ }^{7}$ If this is so, then it clearly begs the question of how this can provide a stable foundation for any kind of functional moral theory at all?

In order to answer this question in the positive, it helps to take a closer look at two related aspects of Spinoza's ethical theory. First, we need to look closer at the status of moral knowledge so as to evaluate how Spinoza's ethical constructivism can be reconciled with an account of moral realism allowing for a meaningful understanding of virtue. Second, we need to look at Spinoza's conception of what constitutes self-preservation beyond mere survival, and, in extension, how self-preservation is conditioned by benevolence and a strong sense of community.

\section{The status of moral knowledge}

For Spinoza, good and evil are only legitimate (and intelligible) values insofar as we approach the world from the perspective of striving things (what Spinoza calls finite modes). Things that strive need external things that help them strive in order to succeed in their striving. As we have just seen, the things that are beneficial for this striving would be good and the things that are inhibiting for it would be evil. When we approach the world from the perspective of nature as substance, however, there is no such thing as good or evil since nature is perfect and all-encompassing for Spinoza. That is, for good and evil to make sense, there needs to be an external model according to which we may judge something either good or evil. For nature there is no such model. Nature is that model itself if you will. For humans, however, being striving things, Spinoza posits the model of a fully rational being (what he calls the free man [E4p66s-E4p77]) who is determined to act by himself alone. In relation to this model we all fall short (insofar as we are not self-sufficient beings (like God or Nature) but very much dependent on external things for our survival and flourishing), but we may posit it as an ideal from where to deduce our practical concepts of good and evil.

Good and evil, from the perspective of striving humans, are universal notions describing whatever will help someone, respectively hinder someone, in becoming more like the ideal of Spinoza's free man. Assuming that good and evil are intrinsic qualities would be a mistake, however, since, in themselves, things are neither good nor evil, but simply things striving (and sometimes failing miserably) to become more empowered and more self-determined (cf. E4pref). Since nature as substance is completely self-determined and self-caused there is nothing external to it that could serve as its model. It is in this sense that good and evil are meaningless terms when we approach nature as substance, but helpful insofar as we approach individual things striving to perfect themselves. In a sense then, Spinoza offers a kind of subjectivism, albeit one that is only subjective insofar as it caters to the need of all finite modes qua striving things. At the same time, it is a form of moral realism in the sense that what is good for one striving thing - i.e. anything that furthers its ability to understand and to cause more - is good for all striving things. Depending on whether we look at the world from the perspective of nature as substance (Natura naturans) or from the perspective of nature as the totality of individual striving things (Natura naturata), then, the status of values like good and evil changes from subjective to objective. 
In order to continue unpacking Spinoza's distinction between intrinsic values and universally valid values - where intrinsic values are claimed to be nonsensical whereas universally valid values are taken to be objectively true - we might draw on Gilles Deleuze's treatment of the crucial difference between morality and ethics in Spinoza. Deleuze argues that Spinoza discards morality, as morality necessarily relies on the notion of intrinsic values, in favor of ethics which is taken to be a concept describing the naturalistic tenets of good and bad derived from an adequate understanding of nature. To this end, Deleuze writes:

In this way, Ethics, which is to say, a typology of immanent modes of existence, replaces Morality, which always refers existence to transcendent values. Morality is the judgment of God, the system of Judgment. But Ethics overthrows the system of judgement. The opposition of values (Good-Evil) is supplanted by the qualitative difference of modes of existence (good-bad). (Deleuze, 1988, p. 23)

This explication is helpful insofar as it illustrates how it is that Spinoza can disqualify intrinsic values on the basis of his dismissal of a law-giving god while still retaining the universally valid values of good and bad on the basis of the pervasiveness of the non-teleological conatus doctrine.

Even though Spinoza proposes an objective notion of what is good for all striving things, it is important to note he does not limit this to traditionally moral concerns. That is, Spinoza's notion of virtue 'lacks any peculiarly moral sense: anything good for us, even obviously amoral activities such as eating or drinking, contributes to our virtue' (Kisner, 2011, p. 81). Besides, as Charles Jarrett suggests, Spinoza's concepts of good and evil are constructivist notions insofar as 'the concept of moral permissibility (or having a right to do something), necessarily applies to everything actual and the concept of what is morally wrong necessarily applies to nothing' $(2014$, p. 73$)$. This, Jarrett argues, marks such a great divergence from our ordinary understanding of moral knowledge that 'his view is better described as rejecting, or not having, moral concepts of what is right, wrong, or permissible' (ibid.). As Michael LeBuffe (2014a) points out, Spinoza's ethical theory posits the nature of moral labels to be psychological which follows from his denial of teleology in nature. Misconceiving nature as a striving thing, Spinoza maintains that humans generally tend to ascribe psychological features to nature, thereby making the mistake of assuming that moral concepts are intrinsic qualities rather than modes of thinking, which is what he takes them to be. Accordingly, in the Appendix to Part 1 of the Ethics, Spinoza writes:

All the prejudices I here undertake to expose depend on this one: that men commonly suppose that all natural things act, as men do, on account of an end; indeed, they maintain as certain that God himself directs all things to some certain end, for they say that God has made all things for man, and man that he might worship God. So I shall begin by considering this one prejudice, asking first [I] why most people are satisfied that it is true, and why all are so inclined by nature to embrace it. Then [II] I shall show its falsity, and finally [III] how, from this, prejudices have arisen concerning good and evil, merit and sin, praise and blame, order and confusion, beauty and ugliness, and other things of this kind. (Ep1app) 
If we understand moral concepts to be psychological labels, or modes of thinking, it follows that even though in a general sense what is good for one striving thing - i.e. anything that benefits its striving to persevere - is good for all striving things, when it come to determining what, more precisely, this would be, we need to look at the particular constitution of the striving thing in question. In other words, the particular constitution of my body and mind determines what is beneficial and what is inhibiting for its perseverance. In this sense, while it is true that it is good for all striving things to persevere in being, it is also true that determining what will help a particular striving thing persevere is a matter of identifying things that empower rather than overpower it. Justin Steinberg offers a useful example illustrating the problems with assuming that what is good for one person is automatically good for another: 'For instance, even if an ideally rational person would have no need to study for a logic exam, it would be patently foolish for most young logic students to emulate the ideal or to take the description of an ideal agent as prescriptive for them' (2014, p. 182).

\section{On self-preservation beyond mere survival and the relative complexity of bodies}

Spinoza understands self-preservation to be something more than a prolonged durational existence. In order to see how this is so we need to look at Spinoza's gradualist understanding of existence. For Spinoza there are degrees of reality and the more reality something has, the more it can be said to exist. The degree of reality of a thing hinges on its activity. Something that is active is more real - relatively speaking - than something that is passive. Of course, everything is passive to some degree. A thing's passivity is determined by the extent to which it depends on other things for its existence. Anything caused by something else is passive to some degree, but the more something can determine itself, the more active it is. In other words, the more things it can cause, the more reality it enjoys. The conatus of every finite thing therefore dictates that it strives to become more active, i.e. to strive to cause more things, so as to be able to exist more in the here and now and not just to live longer.

Certain things are more successful in this endeavor than others. For Spinoza, this depends on the complexity of the individual. A highly complex individual - such as a human being - is composed of many simpler bodies, and can therefore be affected by and affect many other bodies. A less complex individual - such as a stone - is composed of fewer interacting parts and is therefore less capable of affecting and being affected. All of this hinges on Spinoza's mechanistic understanding of the world. Everything is understood in terms of bodies moving and interacting. Even thoughts are approached this way. According to Spinoza's parallelism each body is mirrored by a thought representing it and so even thoughts can be explained in terms of the moving and interacting bodies they represent. This is the reason why more complex bodies are paralleled by more complex minds. They are composed of many smaller interacting parts, and each of these parts has a corresponding idea. The result, as Spinoza points out in E2p13s, is that 'in proportion as a body is more capable than others of doing many things at once, or being acted on in many ways at once, so its mind is more capable than others of perceiving many things at once.'

Certain things, Spinoza claims, are good (qua empowering) for all rational people. Since rational people are assumed to have enough in common to benefit from roughly (although not precisely) the same things, it is good for them to aspire for these things while avoiding 
other things. These things, then, amount to a virtuous character geared for living a life according to the guidance of reason. One such thing is friendship and another is benevolence. This may seem contradictory given Spinoza's focus on self-preservation. The fact is, however, that self-preservation is greatly benefited by friendship and by benevolence (Nadler, 2014). To understand this it helps to recall Spinoza's conception of an individual as a body made up of many smaller bodies. The human body makes for one such complex individual made up of many smaller parts that are 'responsive to one another in [a] systematic way' (Della Rocca, 1996, p. 207). But the human body can also make for one such part combining with other parts providing that they are similar enough to respond to one another systematically. Spinoza's conception of an ideal society is therefore of a great body made up of many interacting parts (qua rational individuals) sustaining a relation of motion and rest among one another. For this ideal to come true, however, many people must combine so that their individual power can be multiplied by joining with others who are like them. ${ }^{8}$ For Spinoza it is therefore rational - and conducive to self-preservation - to form friendships so as to become more powerful and be able to better withstand the threat of being overpowered by external forces. Part of this involves acting benevolently, so as to help people become more rational, and thereby more like oneself. In this way, we help ourselves persevere in being by helping others strive to do the same. This is conditioned by the fact that '[a] thing that shares my nature must, like anything, strive to preserve its own nature; and because its own nature is like my nature, it is therefore necessarily striving to preserve my nature' (Nadler, 2014, p. 49). It is therefore rational to help others, not out of pity or because we hope that they will give us something in return, but because helping them become more rational is a way of helping ourselves. Self-preservation, then, is at the same time conceived as an egoistic striving to empower oneself (by E3p6) and a bedrock for a flourishing community insofar as it functions by uniting many people striving for the same thing (by E4p18s).

\section{Egoism and moral education}

This brings us right up to the important question of how Spinoza's ethical and psychological egoism would shape an account of moral education. From the above it is evident that a model of moral education based on Spinoza's ethical theory would have to adjust to the fact that self-preservation is conceived as the foundation of virtue. Since successful selfpreservation is a matter of finding out what empowers us and what does not, this means that moral knowledge (to some degree) is a matter of practical experimentation and, in turn, that one of the central objects of moral education would be to construct viable (productive) notions of good and evil. As already discussed, good and evil are not intrinsic qualities but rather psychological labels insofar as what helps us persevere is good and what hinders us from this endeavor is bad. ${ }^{9}$ To the extent that we are similar in nature and that we all strive to become more rational, however, there are certain things that are good for us all. Spinoza writes of these things in terms of commands of reason and they amount to rules of living well that will benefit the rational person insofar as they will provide means through which rational people can be joined together in a rational community. These are seemingly simple rules dictating that it is beneficial to always repay hate with love as love can conquer hate (E4p46d, E4p46s); that a smaller present pain is preferable to a greater future pain and, correspondingly, that a greater future joy is preferable to a lesser present joy (E4p65); that friendship is beneficial for the rational person (E4p18s, E4p35s); and that the greatest pleasure one can aspire for is that of a mind guided by reason (E4p52). These rules are not 
exhaustive and they will not automatically lead to a virtuous life, but they will, if transformed into educational tools by the educator, provide a sort of guiding principle that will help ensure that the student's striving for self-preservation will be guided by reason rather than by passions.

When we are guided by our passions we tend to pursue things that we mistake for the good - such as money or fame - but that in reality contribute to our bondage because they make us dependent upon external things over which we have very little control. It takes education to be able to learn what it is that truly benefits my striving to persevere - a better understanding of myself and the world around me - and what does not. The teacher - acting out the role of a moral exemplar - may illustrate virtues such as generosity and benevolence in a general sense by acting on them, but when it comes to the finer nuances of identifying what is beneficial and what is not, this must be experienced by individual students in situ. The role of the teacher then takes on a slightly different characteristic, being the one who oversees the cognitive training of the students, ensuring that their experimentation is guided by reason rather than by passions. This is where the dictates of reason play an important part as tools for the teacher to use in directing the students' attention toward things that they can be reasonably sure will be beneficial for them even if the exact result will be known only after the fact as it were. As LeBuffe notes: 'By conceiving of a recta ratio vivendi and joining it to memory we can exploit the resources of the imagination to make it serve intellectual ends' (2014b, p. 189).

This will be a way of ensuring that the passions do not derail the imagination into seeking out things that are detrimental for the student. In guarding against the dangers of the passions, the teacher's role may be described in terms of what LeBuffe (2010) calls the perspective of the 'optimistic nutritionist.' It is the job of the optimistic nutritionist to make sure that the relation between laetitia (joy) and perseverance is always secured so that students do not 'mistakenly, anticipate laetitia in other things [i.e. things that are not conducive to perseverance] and so desire them' (p. 112). The analogy of the optimistic nutritionist conceives of laetitia and perseverance in terms of sweetness and nutrition. Some things, like candy, are sweet yet not very nutritious. Other things, like fruit and nuts, are both sweet and nutritious. Since both candy and fruit are sweet we might easily mistake one for the other, thinking that what is sweet is always good for us. A diet of candy will prove this wrong however. The optimistic nutritionist takes advantage of the natural connection between sweetness and nutrition, offering guidance so that we may seek out what is sweet and nutritious and avoid what is sweet yet unhealthy. LeBuffe explains:

Children always try to eat healthy foods, in a way, even though they don't know it. As we all know they hunt around for sweet things to eat, and try to avoid bitter ones. The sweetest things that one can eat continually over a long period of time, though, like oranges and pecans, are really healthy. We can help them by showing them which foods really are healthy and convincing them of what is true, that those really are the ones that bring a life full of sweetness. (LeBuffe, 2010, p. 113)

Identifying the many different things that are both sweet and healthy (in relation to any one particular individual) is a matter of practical experimentation. Distinguishing between things 
that are good and things that are bad, in more general sense, however, is a matter of principle. While the teacher can help students make this distinction in a general sense, it is up to the students themselves to equilibrate their sense of what is good for them specifically. It is important to keep in mind that the optimistic nutritionist is an analogy and that it needs to be understood not in terms of a guide helping students identify what will help them sustain themselves in a strictly physical sense, but in terms of a guide helping them identify anything that will strengthen their conatus. Moral education therefore involves adhering to the dictates of reason - and having these illustrated by the teacher as a role model and moral exemplar - and engaging in a cognitive training where these guiding principles can help students distinguish what is good from what is not in a process of practical experimentation. Again, we see how this emanates from the egoistic striving to persevere in being while also functioning on a broader social level insofar as all rational people benefit from a solid link between sweetness and nutrition/laetitia and perseverance.

With regards to the constraints of egoism placed on moral education, another important aspect - besides the fact that Spinoza's denial of the objectivity of moral knowledge introduces a demand for practical experimentation - involves changes in the traditional relation between the teacher and the student. Again, this change results from the notion that self-preservation is the foundation of virtue.

Self-preservation becomes the driving force of moral education insofar as the desire to become more rational motivates the teacher to help the student become more rational so that the teacher, in turn, can mold the student into a moral exemplar for him or her to emulate. This is so because, as Della Rocca notes, 'if we perceive others to desire to be more rational, more active, more powerful, we will tend to emulate that desire and also seek to become more powerful' (2008, p. 198). Far from being an altruistic teacher (in the sense of a self-sacrificing teacher), the Spinozistic teacher is always motivated by his or her egoistic striving for self-preservation and flourishing (much like anyone else). Because the success of this striving hinges on the moral development of the students, however, the selfpreservation of the teacher is always conditioned by the overall moral state of the greater community, in this case the class. This may come across as a fairly counterintuitive conception of a good teacher, insofar as a good teacher is commonly depicted as an altruist, teaching for the sake of his or her students (and, in extension, for the sake of the betterment of society) but not primarily for him- or herself. These things are not contradictory for Spinoza however. In fact, as we have just seen: 'Self-seeking - traditionally opposed to rational virtue - now becomes its foundation' (Lloyd, 1996, p. 9). As we have also seen, selfseeking is conditioned by benevolence insofar as we need to establish friendships and help people become more rational so that we can benefit from their increased rationality. This means that Spinoza 'need not deny the phenomena of altruism. He is committed only to the view that the causal origins of these phenomena always lie in a single psychological force, which is the individual's own endeavor for his or her own self-preservation' (Garrett, 1996, p. 303). Hence, the Spinozistic teacher starts out by acting out the role of a moral exemplar, yet his or her reasons for doing so are not at all selfless but it is rather done so that the students may become more rational so that the teacher can emulate them in return.

These, then, are two fundamental aspects of a Spinozistic model of moral education following from the constraints introduced by Spinoza's ethical and psychological egoism. 
They suggest that (1) Spinoza's constructivism introduces a demand for practical experimentation that would not be necessary if there was such a thing as moral knowledge in an objective sense, and (2) that the Spinozistic teacher teaches primarily for the sake of him or herself, helping others as a way of self-empowering. Besides these two effects of Spinoza's ethical and psychological egoism, there is another, perhaps more serious, challenge facing a Spinozistic model of moral education. This would be Spinoza's apparent denial of moral responsibility. We will deal with this challenge in the following section.

\section{Moral education without moral responsibility}

Spinoza's denial of moral responsibility is an effect of his denial of a free will (E2p48). Spinoza clearly rejects the idea of a free will as a superstition if by a free will we mean an unrestrained or uncaused will. This is an effect of Spinoza's causal determinism. Spinoza's causal determinism dictates that all things are causally determined (by E1a2) and that there cannot be anything exempt from natural causation. This means that there can be no such thing as a spontaneous expression of will since this would violate Spinoza's naturalism. Spinoza's naturalism, in turn, opens up for his uncompromising necessitarianism stating that: 'In nature there is nothing contingent, but all things have been determined from the necessity of the divine nature to exist and produce an effect in a certain way' (E1p29). Lacking the knowledge of many of the causes determining us to act, we tend to assume that our actions are caused by the spontaneous expression of our free will. This, for Spinoza, is clearly a mistake, and it says more about our inability to perceive the world such as it really is than it does about the supposed capacity of our will power. Spinoza dismisses the notion of a free will in a letter to G.H. Schuller along the following lines:

This, then, is that human freedom which all men boast of possessing, and which consists solely in this, that men are conscious of their desire and unaware of the causes by which they are determined. In the same way a baby thinks that it freely desires milk, an angry child revenge, and a coward flight. Again, a drunken man believes that it is from his free decision that he says what he later, when sober, would wish to be left unsaid. (Letter 58)

Because the free will is deemed an illusion, it follows that the concept of moral responsibility is also seriously threatened insofar as this hinges on our ability to direct events in accordance with our free will. Spinoza seems relatively unconcerned by this however. Responding to the accusation that this would lead to a general state of immorality and disorder, Spinoza writes: 'As to his final remark, that "on this basis all wickedness would be excusable," what of it? Wicked men are no less to be feared and no less dangerous when they are necessarily wicked' (Letter 58). Spinoza takes care to distinguish between the act of placing blame and the enforcement of an order protecting all rational people. His reasoning goes as follows:

A horse is excusable for being a horse, and not a man; nevertheless, he needs must be a horse and not a man. He who goes mad from the bite of a dog is indeed to be excused; still, it is right that he should die of suffocation. Finally, he who cannot control his desires and keep them in check through fear of the law, although he is to be excused for his weakness, nevertheless cannot enjoy 
tranquility of the mind and the knowledge and love of God, but of necessity he is lost. (Letter 78)

For Spinoza, which is evident from the above, virtue is its own reward and vice is its own punishment (Letter 43). This does not mean, however, that evil acts should go unchecked. Evil acts (which is another way of saying that they are harmful to people) should be prevented because they threaten the well-being of the rational community, but this, however, has little to do with praise or blame.

A Spinozistic model of moral education, then, would need to be conceived in terms of an education beyond praise or blame. There is no sense in which a student can be disciplined or frightened into becoming virtuous. The benefits of becoming virtuous should be enough rewards in themselves, without the teacher having to reside to praising his or her students. Likewise, the drawbacks of acting in ways that are not virtuous will be punishment in itself. The practice of blaming someone for something that they are not the true cause of is irrational for Spinoza. Remember that when we act passionately we are passive, and this means that we are caused to act (i.e. overpowered) by more powerful things external to us. We may believe ourselves to be responsible for these actions but this is only because we are unable to conceive of their true causes. The only time we are truly responsible for our own actions is when we are active, i.e. when we are the true cause of our actions. When we are active we are virtuous by definition since our power of acting is equivalent to our virtue (4D8). This means that while we may be responsible for some of our actions, these actions are never immoral insofar as they are always aligned with our nature to preserve our own being, which, as we have seen, is the only foundation of virtue.

I would argue that the displacement of focus from assigning moral responsibility to improving the understanding of natural causation is what sets a Spinozistic model of moral education apart most markedly from other dominant accounts of moral education. In Chapter 1 of The self beyond itself (2013), Ravven sets out to outline the notion of the free will as a common denominator of the four major models of moral education in a contemporary American context. To this end she claims that, as different as they may be in some regards, they all share 'a reliance on a notion of free will, decision making, and obligation to follow discrete moral principles as guides for action' (p. 46). The four models that Ravven refers to are contemporary character education, values clarification, Kohlbergian cognitive moral development and a care ethical approach to moral education. Accordingly, she argues that '[a]ll four models seem to presuppose that social problems are moral problems and are due to aggregates of bad individual choices and personal decisions' (p. 41). As we have seen, from a Spinozistic perspective, the free will is deemed an illusion and as a result assigning moral responsibility becomes deeply problematic.

While moral responsibility, in the sense of praise and blame, appears incompatible with Spinoza's naturalism, we might still say that transforming students into people who are responsible for their actions - meaning that they are active rather than passive - is a central goal of moral education. The way to go about this is to encourage students to learn more about themselves and their affective responses to external things so that they may understand their affects to the point where they become the adequate cause of some of their actions. This - to become the adequate cause of some of our actions - is Spinoza's 
definition of freedom insofar as freedom pertains to humans qua finite modes. This is the highest level of self-determination we can hope for, being necessarily caused by, and dependent on, external things. Since absolute freedom for Spinoza amounts to being completely self-caused and self-sustained (E1D7) it follows that this is a kind of freedom that we can never attain. In contrast, the weaker notion of freedom that involves being the adequate cause of some of our actions is a gradual process of deliberation that serves as a motivation for moral education insofar as a virtuous character is the same as living according to the guidance of reason. From this it becomes clear that Spinoza's concept of human freedom corresponds with his concept of power of acting, which in turn is equivalent to his notion of virtue. Self-preservation, being the foundation of virtue, is therefore conceived as an empowering and liberating project geared to overcoming passive responses and seeking out the things that will empower us and bring us lasting joy. It is important to underline, however, that it is not liberating in the sense that it allows us to act otherwise. Instead, it is liberating in the sense that understanding the causal necessity of our actions will bring us peace of mind and will serve to protect us from the anxiety of wishing that we had acted differently when in fact we could not.

\section{Conclusion: a model of moral education or a moral model of education?}

A Spinozistic understanding of moral education will clearly need to adapt to Spinoza's naturalistic account of the human mind, which means that affects are considered in mechanistic terms as increases and decreases in power, and that a virtuous character amounts to a life guided by a rational understanding of what is empowering and what is not. As a result, moral education would be centered on finding out what empowers a particular student and what diminishes his or her power of acting. As we have discusses, part of this involves finding this out through practical experimentation, where the student needs to experience many things so as to be able to judge with some precision which are good and which are not. Part of it involves letting this process of experimentation be guided by rational principles guarding, on a more general level, against the dangers of excess and defect. In Spinozistic terms this means finding ways of aligning laetitia with perseverance. This is a matter of cognitive training insofar as certain things that are sweet yet detrimental for us needs to be avoided while the sweet and empowering needs to be sought out. It is not enough, however, to simply expose one's students to many different things. If it were so then we would not need education at all. The trick, instead, is to reorder the ideas that we have by 'breaking old associations between accidentally formed ideas and replacing them with new associations, ones forged according to the order of reason' (Marshall, 2013, p. 187) - thereby turning inadequate ideas into adequate ideas. It is the role of the teacher to oversee this cognitive training, reminding of the dictates of reason much like the optimistic nutritionist reminds of the important connection between sweetness and nutrition.

The problem is that from the perspective of moral education it becomes difficult to separate the specific moral aspects from more general epistemological concerns. Since Spinoza's ethical theory amount to a reflection of his epistemological account (dressed up in traditional moral terminology) there is no tangible boundary between the descriptive aspects of the account of human nature - as the striving to persevere in being - and its normative upshot - that whatever furthers this striving is good for us. Hübner elaborates: 
As a result, for Spinoza to say that all things "strive to persevere in being" is not to name some end that things have when striving, some future or possible state of being that they all want to reach. It is rather to name a logically necessary property common to all essential effects. (Hübner, Forthcoming, p. 21)

Lacking the notion of natural ends, Spinoza's ethical theory is deprived of a crucial part of what other available accounts of moral education appears to take for granted; that because moral knowledge is taken to designate certain specific aspects of the good life - rather than designating anything that furthers our striving to persevere - moral knowledge may be understood in terms of an end in itself. In relation to this end a student's responses to various situations may be evaluated and deemed more or less moral. Consequently, the aim of guiding a student's decision making relative to this end becomes a central part of moral education. For Spinoza, however, where the concepts of 'will, appetite, and desire all identify from the perspective of fundamental concepts ("thought" and "extension"), one and the same causal dimension of a thing's essential nature' (Ibid., p. 32), the discussion of moral education risks becoming redundant since its aim of advancing the general understanding of the students would apply to any aspect of education in equal measures. This is so since ethics, for Spinoza, may be described in terms of 'a category of his metaphysics' meaning that '[i]t is not a grounding or a derivation of ethics from metaphysics, but a reduction of the former to the latter' (Ibid., p. 37).

While a Spinozistic model of moral education appears to amount to an account of education general enough to encompass all of education, it remains true that it is a moral account of education. Even though it may not be appropriate to label it a model of moral education given that moral education without moral agency may be too far removed from what we generally require of moral education - I would argue that it provides a productive understanding of the relation between morality and epistemology in education. It is productive insofar as it confronts the traditional philosophical conflict 'between desires and appetites on the one hand and will on the other' (Ibid., p. 31). By subordinating all of these concepts to his strict naturalism, the question of morality becomes a question of understanding our nature as striving things where freedom is not freedom from constraint but the freedom to understand and accept our limited control over ourselves and the world in which we live. Consequently, it may be appropriate to talk of a moral model of education rather than a model of moral education. This way, Spinoza's radical naturalization of morality makes for an intriguing framework for all of education rather than a model for understanding the specifically moral aspects of education. While the aim of education is moral insofar as it is geared to furthering the students' striving to persevere, this aim is realized through the improvement of the understanding of nature rather than through the inculcation of moral values.

\section{List of references}

Aloni, N. (2008). Spinoza as educator: From eudaimonistic ethics to an empowering and liberating pedagogy. Educational Philosophy and Theory, 40, 531-544

Bennett, J. (1984). A study of Spinoza's Ethics. Indianapolis, IN: Hackett Publishing. 
Curley, E. M. (1969). Spinoza's metaphysics: An essay in interpretation. Cambridge, MA: Harvard University Press.

Dahlbeck, J. (2016). Spinoza and education: Freedom, understanding and empowerment. London \& New York: Routledge.

Deleuze, G. (1988). Spinoza: Practical Philosophy. San Francisco, CA: City Lights Books.

Della Rocca, M. (1996a). Spinoza's metaphysical psychology. In D. Garrett (Ed.), The Cambridge companion to Spinoza (pp. 192-266). Cambridge: Cambridge University Press.

Della Rocca, M. (1996b). Representation and the mind-body problem in Spinoza. Oxford: Oxford University Press.

Della Rocca, M. (2008). Spinoza. London, Routledge.

Derry, J. (2006). The unity of intellect and will: Vygotsky and Spinoza. Educational Review, 56, 113-120.

Garrett, D. (1996). Spinoza's ethical theory. In D. Garrett (Ed.), The Cambridge companion to Spinoza (pp. 267-314). Cambridge: Cambridge University Press.

Hübner, K. (Forthcoming). Spinoza's unorthodox metaphysics of the will. In M. Della Rocca (Ed.), The Oxford handbook on Spinoza (pp. 1-41). Oxford: Oxford University Press.

Israel, J. (2002). Radical enlightenment: Philosophy and the making of modernity 1650-1750. Oxford: Oxford University Press.

Jarrett, C. (2014). Spinozistic constructivism. In M. J. Kisner \& A. Youpa (Eds.), Essays on Spinoza's ethical theory (pp. 57-84). Oxford: Oxford University Press.

Kisner, M. J. (2011). Spinoza on human freedom: Reason, autonomy and the good life. Cambridge: Cambridge University Press.

Kisner, M. J. \& Youpa, A. (Eds.) (2014). Essays on Spinoza's ethical theory. Oxford: Oxford University Press.

Kraut, R. (2014). Aristotle's ethics, The Stanford encyclopedia of philosophy (Summer 2014 Edition), Edward N. Zalta (Ed.), URL = <http://plato.stanford.edu/archives/sum2014/entries/aristotle-ethics/>.

Kristjánsson, K. (2007). Aristotle, emotions, and education. Aldershot: Ashgate.

Kristjánsson, K. (2015). Aristotelian character education. London: Routledge. 
LeBuffe, M. (2010). From bondage to freedom: Spinoza on human excellence. Oxford: Oxford University Press.

LeBuffe, M. (2014a). Spinoza's psychological theory, The Stanford encyclopedia of philosophy (Spring 2014 Edition), E. N. Zalta (Ed.), URL = <http://plato.stanford.edu/archives/spr2014/entries/spinoza-psychological/>.

LeBuffe, M. (2014b). Necessity and the commands of reason in the Ethics. In M. J. Kisner \& A. Youpa (Eds.), Essays on Spinoza's ethical theory. (pp. 197-220). Oxford: Oxford University Press.

Lloyd, G. (1996). Routledge philosophy guidebook to Spinoza and the Ethics. London: Routledge.

Lloyd, G. (1998). Spinoza and the education of the imagination. In: A. O. Rorty (Ed.), Philosophers on education: New historical perspectives (pp. 157-172). London \& New York: Routledge.

Marshall, E. (2013). The spiritual automaton: Spinoza's science of the mind. Oxford: Oxford University Press.

Melamed, Y. Y. (2011). Spinoza's anti-humanism: An outline. In C. Fraenkel, D. Perinetti \& J. E. H. Smith (Eds.), The rationalists: Between tradition and innovation (pp. 147-166). Dordrecht: Springer Netherlands.

Melamed, Y. Y. (2013). Spinoza's metaphysics: Substance and thought. Oxford: Oxford University Press.

Nadler, S. (2013). Baruch Spinoza, The Stanford encyclopedia of philosophy (Fall 2013 Edition), Edward N. Zalta (Ed.), URL = $<$ http://plato.stanford.edu/archives/fall2013/entries/spinoza/>.

Nadler, S. (2014). The lives of others: Spinoza on benevolence as a rational virtue. In M. J. Kisner \& A. Youpa (Eds.), Essays on Spinoza's ethical theory (pp. 41-56). Oxford: Oxford University Press.

Puolimatka, T. (2001). Spinoza's theory of teaching and indoctrination. Educational Philosophy and Theory, 33, 397-410.

Ravven, H. M. (1990). Spinoza's materialist ethics: The education of desire. International Studies in Philosophy, 22, 59-78.

Ravven, H. M. (2013). The self beyond itself: An alternative history of ethics, the new brain sciences, and the myth of free will. New York: The New Press.

Sanderse, W. (2015). An Aristotelian model of moral development. Journal of Philosophy of Education, 49, 382-398. 
Singer, B. A. (1988). Spinoza on returning hatred with love. Journal of Moral Education, 17, 3-10.

Spinoza, B. (1985). Ethics. In E. Curley (Ed. and trans.), The collected works of Spinoza, Vol. 1 (pp. 408-617). Princeton: Princeton University Press.

Spinoza, B. (2002). The Letters. In M.L. Morgan (Ed.) and S. Shirley (trans.), Spinoza: Complete works (pp. 755-959). Indianapolis, IN: Hackett Publishing.

Steinberg, J. (2014). Following a recta ratio vivendi: The practical utility of Spinoza's dictates of reason. In M. J. Kisner \& A. Youpa (Eds.), Essays on Spinoza's ethical theory (pp. 178-196). Oxford: Oxford University Press.

\footnotetext{
${ }^{1}$ Matthew J. Kisner (2011) argues that Spinoza's robust notion of virtue and his largely eudaimonistic concept of the good life qualify him as a kind of virtue ethicist, even if his particular brand of virtue ethics comes across as being somewhat unorthodox in ways that will be discussed later in this paper.

2 Passages in Spinoza's Ethics will be referred to using the following abbreviations: a(-xiom), $c$ (-orollary), d(-emonstration), D(-efinition), p(-roposition), s(-cholium) and pref(-ace). DOA refers to $D$ (-efinition) $O(-f)$ the $A(-f f e c t s)$. Hence, $4 p 22 c$ refers to the corollary of the $22^{\text {nd }}$ proposition of part 4. All references to the Ethics are to Curley's (Spinoza, 1985) translation. ${ }^{3}$ Unlike Descartes who reserves a special metaphysical position for humans as a kind of selfsustained substance - albeit one that is caused by God - thereby insuring that the doctrine of the immortality of the human soul is safeguarded.

${ }^{4}$ Spinoza is a panpsychist in the sense that he believes that each body, no matter how simple and inactive, is paralleled by a mind. For a more developed discussion on Spinoza's panpsychism see Della Rocca (1996b, pp. 7-9) and Bennett (1984, pp. 135-139).

${ }^{5}$ References to Spinoza's correspondence are to Shirley's translation in Spinoza: Complete works (Spinoza, 2002).

${ }^{6}$ In order for this to make sense with regards to simpler body/minds it should be noted that the word striving, in this context, does not denote an intentional kind of striving but rather a tendency to persist in motion unless prevented to do so from without.

${ }^{7}$ In fact, for me to preserve myself I will need to destroy other things/bodies, such as the different foods I need to consume in order to vitalize and strengthen my own body.

${ }^{8}$ Accordingly, in 4p18s Spinoza writes: 'For if, for example, two individuals of entirely the same nature are joined to one another, they compose an individual twice as powerful as each one. To man, then, there is nothing more useful to man. Man, I say, can wish for nothing more helpful than that all should so agree in all things that the minds and bodies of all would compose, as it were, one mind and one body; that all should strive together, as far as they can, to preserve their being; and that all, together, should seek for themselves the common advantage of all.'

${ }^{9}$ In 3p9s Spinoza writes that 'we neither strive for, nor will, neither want, nor desire anything because we judge it to be good; on the contrary, we judge something to be good because we strive for it, will it, want it, and desire it.'
} 